\title{
Searching for Active Learning Methods for New Product Development Purposes
}

\author{
Anderson Dalmaz', Osmar Possamai' ${ }^{1}$, Aaron J. Armstrong2 \\ ${ }^{1}$ Production Engineering Department, Federal University of Santa Catarina (UFSC), PPGEP/CTC/UFSC, \\ Florianópolis, Brazil \\ ${ }^{2}$ Industrial Engineering Program, Milwaukee School of Engineering, Milwaukee, USA \\ Email: andersondalmaz@gmail.com,osmarpossamai@gmail.com,armstrong@msoe.edu
}

Received 12 December 2015; accepted 28 December 2015; published 31 December 2015

Copyright (C) 2015 by authors and Scientific Research Publishing Inc.

This work is licensed under the Creative Commons Attribution International License (CC BY). http://creativecommons.org/licenses/by/4.0/

(c) (i) Open Access

\begin{abstract}
Individual learning is the base of the company learning. And learning on product development contexts is related to product success [1] [2]. Improving effectiveness of individual learning in a new product development (NPD) context could bring results to the company. Active learning (AL) is largely studied in literature and shows promising results to improve learning. Its objective is to increase learner engagement [3], having its fundamentals based on cognitive aspects of humans, as attention [3]. But what are the existing approaches? Could they be used in NPD contexts to increase efficiency of learning? The objective of this article is to address the first question (i) identifying approaches considered AL from literature. This article presents the list of approaches found and its descriptions. This descriptions will be used for the next steps of this research to be presented in future articles (i) identifying AL approaches already used in industry and (ii) suggesting a method aiming to increase learning in NPD context.
\end{abstract}

\section{Keywords}

Learning, Product Development, Active Learning

\section{Introduction}

Individual learning is the basic unit for the company learning. And learning is often correlated with success [1] [2] of the new products. Learning enables individuals to change their behavior according to their environment [4].

In the NPD context, individuals can change their behaviors through informal ways, as with their own gain of experience [5] [6], registrations [7], checklists [6] [7], with project leaders [5], stories [8], metaphors [8], contact 
with friends and colleagues of the company. Despite the fact that this ways are the most commonly used [4] they are not manageable by its own nature [9].

Experiences also can be gathered in events specifically designed to learning as after action review [10] and post-mortem review [5]-[11]. Individuals can also learn using company documentation [5]-[13], as formal checklists [6], lessons learn data bases [10], micro articles [10]-[14] and histories [10]-[15]. All this learning can be accessed directly or through training materials.

All these means of learning transfer are critical to the employees learning and to the success of the company. Could it be possible to make learning transfer more effective in NPD?

Even though there are many ways for individuals to learn in the professional environment, any of the means above considers cognitive aspects of the learner, as motivation and emotions, in its fundamentals.

Active learning (AL) is a group of techniques of engagement of the learner. Its use has showed promising results in academic environment, but varying among different researches [3]. It's already being used in professional NPD environment [16], but just by a few researches and with low measured supportive evidences.

In conclusion, AL is an interesting target of research because its fundamentals are based on the learner, it has promising results and it isn't much explored in NPD context.

This article is part of a research with the objective to create and to use an AL in a NPD environment aiming to improve individual learning in NPD context. Before the final objective is necessary firstly to understand existing approaches, the objective of this article is to (i) identify what approaches are considered active learning (AL) from literature.

\section{Methodology}

In order to find $\mathrm{AL}$ approaches from the literature, a search on the Scopus database was performed for articles that contained the words "active learning" in its title, abstract or keywords. 9472 articles were found on 25 October 2015. From them 312 were classified as reviews, which have its title and abstract read. When it indicated that could add different AL approaches, the article were read completely. Articles cited that were considered relevant to were also include in the base of articles.

\section{Active Learning Overview and Research Pitfalls}

A lot of different active learning approaches are used with the same terms [3] and some techniques are considered hybrids [17] presenting characteristics of more than one approach. As a result, general definitions are pitfalls [3].

However, active learning can be summarized as group of methods and techniques of student engagement. Techniques that make the student think and reflect on the subject rather than just receive it passively [3]. In the professional point of view, active learning application can works as a pillar of the culture of learning [16], making part of the strategy of the company.

Different active learning techniques results are hard to be compared [3]. Because of the definition and hybridism issues previously commented and because many techniques have good results in one variable and bad in others [3] comparing different contexts.

There is another pitfall indicated by Prince [3] that many of the techniques tested don't have a large quantity of variables measured [3], as examples, knowledge, students attitudes and retention [3]. One reason to this lack of measurement is that some variables are difficulty to be measured, as lifelong learning, for example [3].

\section{Active Learning Approaches}

\section{From AL Literature}

In this chapter is presented approaches found in AL literature. It is not discussed applicability of the approaches in the NPD environment.

Active learning approaches vary much in complexity, from simple activities in class room until immersive worlds constructed in computers.

Some examples of simple supportive activities are active listening and writing [18]. Where students speak and write what they had studied with their own words. Variations of these are students explaining the content to one another, submitting questions to the teacher, writing summaries and writing notes in groups [18]. 
Watching movies while answering questions, hearing comments from the instructor or even producing its own movies are examples of visual based activities [18].

Additionally, simple activities can be performed in groups also. According to Prince, groups activities can be divided in two. Collaborative ones, where "students work in groups toward a common goal" [3]. And cooperative learning, similar to the previous, but students are evaluated individually [3].

Some of the listening, writing and visual-based examples can be considered as group activities. Other examples are debates, peer teaching and role-play [18]. The three next methods described are group activities with particularities.

Process oriented guided inquiry learning (POGIL) is method that uses questions to guide a subject discussion [17]. Usually follows three phases: exploration, concept invention and application, something close to the scientific method [19]. The guide questions need to be prepared before class by an instructor. This needs to be done in a precise way, in order to the students found expected conclusions [17]. Students are arranged in groups receiving instructor supports when needed [17]. This method is used mainly in undergraduate classes and also in laboratory experiments, mostly related to science [17]-[20] as biochemistry [21] and ecology [22].

Peer led team learning (PLTL) is a method with the particularity that students lead the groups. They are recruited and trained for this role. They lead groups of six to eight classmates during workshops, solving previously structured problems [17]-[24]. This method showed good results [25] when comparing grades of tested classes with controlled groups. And, in other perspective, students with the leader's role received a great experience, gaining knowledge about the subject, personal skills, as communication and professional skills as leadership [26].

Team based learning (TBL) is similar to the previous techniques described. It is composed of groups of four or five, which passes through a complex problem solving step prepared in advance [23]. The difference is the existence of a discussion among all the groups in the end of the activity [23].

Studio-based learning (SBL) differs from the others due to its hands on application. It's used mainly in architecture, internal design and industrial design [23]. The teacher is an instructor that teaches through inquiry and criticism of the work of small groups [23].

A method that was largely studied in the literature is Problem-based learning. It's a very broad method used in many areas and ways. PBL research started in medicine [17] and it's still where most of the publications came from. Many definitions are encountered in the literature [3]-[17]. But many of them correlate PBL with a way of engagement [3]-[27] of the student in an active way, using open ended problems before the introduction of concepts to be learned [27].

According to Bridges and Hallinger, there are two types of PBL, depending who decides learning objectives, resources and guiding questions. Student centered and problem centered PBL. The first one student defines the features mentioned, and the latter, the instructor.

Limitations identified by Bridges and Hallinger for student centered PBL is that, due to the students lack of knowledge, they commonly choose problems that do not cover the minimum learning objectives that the faculty considers important. Additionally, they can have problems with time to locate resources needed.

Another point is that, PBL methodology itself doesn't attain its objectives. It needed to be fostered in a learning environment, that supports students with patience, accepts risk taking and promote high expectation [27]. Some authors have suggested processes of how to develop a PBL [28] others how to implement PBL programs in classrooms [27].

Recently technology is being used as an important support in learning. And it is having more attention from researchers. It enables self learning, distance learning, social interactions, immersive experiences through games and simulated worlds.

Students get in touch with content directly using websites, without the need of a teacher or an instructor. Web based learning (WBL) is the use of websites considering active learning aspects, enabling students of self learning, distance learning and flexible schedules [29]. It can be used to support traditional methods or as the only mean [29]. The teacher, acting here as web designer [29], can use photos, links to related subjects, questions with answers [29] and animations [30] along the web site in order to retain student attention. As example, Sinav and Ambron developed a program accessible by the internet where students can explore the anatomy of small and complex human structures, becoming much easier to understand them. In the literature researchers already suggested guidelines for site structure [31] and implementation [32].

It's possible to promote active learning increasing interaction of the stakeholders using social networking (fa- 
Table 1. Summary of the AL methods identified in the literature.

\begin{tabular}{c} 
Methods \\
Active listening \\
Active writing \\
Visual-based learning \\
Process oriented guided inquiry learning \\
Peer lead team learning \\
Team based learning \\
Studio based learning \\
Problem based learning \\
Web-based learning \\
Social medias \\
Games \\
\hline
\end{tabular}

cebook, myspace, linkedin, blogs and twitter). The use of social tools as means of learning are new, in consequence, researches are still gathering data, users are in experimental phase and some teachers/institutions do not accept its use [33].

Another concept is the use of simulations and games. Prensky [34] describe it as something recreated, approximated, that imitates reality or made predictions. They are much used to support professional training in medical, military and business training [34]. Simulation can lead you to the learning, without motivation you to continue until de end [34]. A simulation can be gamificated and became a game and an active learning tool.

Gamification concept is the use of games elements and design techniques in non concepts contexts [35], for example, use of avatars, levels, points, leaderboards, content unlocking and boss fights. The use of learning games is a differentiation because the new generation is used with games. Games motivate, engage and are fun [34]! Besides the use of games due motivational reasons, Freitas [36] gives examples of another uses as practice of skills, therapy and professional practicing. There are a lot of types of games described in the literature, for example, virtual or digital games, immersive games, progressive games, board games and role play games.

The summary of all approaches described in this chapter are in Table 1.

\section{Conclusions}

The objective of this article was to identify what is considered active learning from literature. Table 1 summarizes approach found and its descriptions are in chapter "From AL Literature".

All AL methods described in this article could be adapted to use inside company NPD area. Many cases from AL literature are related with classroom activities or group activities, performed in different ways to engage students. This expertise could be adapted for company training sections with no restrictions.

Real cases from the company could also be adapted to create problem based on learning methods or games. Professional social media existing in the company could be adapted also to be used to exchange practices and share learning. Which of these possibilities are already used?

Based on that possibilities, the suggestion of next steps are summarized below:

1. Identifying AL approaches already used in industry;

2. Suggesting a method aiming to increase learning in NPD context.

\section{References}

[1] Lynn, G.S., Mazzuca, M., Morone, J.G. and Paulson, A.S. (1998) Learning Is the Critical Success Factor in Developing Truly New Products. Research Technology Management, 41, 45-51.

[2] Maidique, M.A. and Zirger, B.J.(1985) The New Product Learning Cycle. Research Policy, 14, 299-313. http://dx.doi.org/10.1016/0048-7333(85)90001-0

[3] Prince, M. (2004) Does Active Learning Work? A Review of the Research. Journal of Engineering Education, 93, 223-231. http://dx.doi.org/10.1002/j.2168-9830.2004.tb00809.x 
[4] Pozo, J.I. (2002) Aprendizes e mestres: A nova cultura da aprendizagem. Artmed, 296.

[5] Wilemon, D. and Meyers, P.W. (1989) Learning in New Technology Development Teams. Journal of Product Innovation Management, 6, 79-88. http://dx.doi.org/10.1016/0737-6782(89)90002-7

[6] Riek, R.F. (2001) From Experience: Capturing Hard-Won NPD Lessons in Checklists. Journal of Product Innovation Management, 18, 301-313. http://dx.doi.org/10.1016/S0737-6782(01)00100-X

[7] Goffin, K. and Koners, U. (2011) Tacit Knowledge, Lessons Learnt, and New Product Development. Journal of Product Innovation Management, 28, 300-318. http://dx.doi.org/10.1111/j.1540-5885.2010.00798.x

[8] Goffin, K. and Koners, U. (2008) Capturing Tacit Knowledge in New Product Development: A Study of Post-Project Reviews. International Journal of Technology Intelligence and Planning, 4, 234. http://dx.doi.org/10.1504/IJTIP.2008.020096

[9] Dalmaz, A., Possamai, O. and Armstrong, A.J. (2015) Methods of Learning in Product Development Contexts. American Journal of Industrial and Business Management, 5, 699-704. http://dx.doi.org/10.4236/ajibm.2015.511069

[10] Schindler, M. and Eppler, M.J. (2003) Harvesting Project Knowledge: A Review of Project Learning Methods and Success Factors. International Journal of Project Management, 21, 219-228. http://dx.doi.org/10.1016/S0263-7863(02)00096-0

[11] Goffin, K. and Koners, U. (2007) Learning from a Post-Project Reviews: A Cross-Case Analysis. Journal of Product Innovation Management, 24, 242-258. http://dx.doi.org/10.1111/j.1540-5885.2007.00248.x

[12] Lynn, G.S., Simpson, J.T. and Souder, W.E. (1997) Effects of Organizational Learning and Information-Processing Behaviors on New Product Success. Marketing Letter, 1, 33-39. http://dx.doi.org/10.1023/A:1007981109972

[13] Lynn, G.S., et al. (1999) Practices That Support Team Learning and Their Impact on Speed to Market and New Product Success. Journal of Product Innovation Management, 16, 439-454. http://dx.doi.org/10.1016/S0737-6782(98)00071-X

[14] Willke, H. (1998) Systemisches Wissensmanagement. Lucius \& Lucius Verlagsgesellschaft, Stuttgart.

[15] Roth, G. and Kleiner, A. (1998) Developing Organizational Memory through Learning Histories. Organizational Dynamics, 2, 43-60. http://dx.doi.org/10.1016/S0090-2616(98)90023-7

[16] Moskiwitz, H. and Ward, J. (1998) A Three-Phase Approach to Instilling a Continuous Learning Culture in Manufacturing Education and Training. Production and Operations Management, 7, 201-209. http://dx.doi.org/10.1111/j.1937-5956.1998.tb00452.x

[17] Eberlein, T., et al. (2008) Pedagogies of Engagement in Science. Biochemistry and Molecular Biology Education, 36, 262-273. http://dx.doi.org/10.1002/bmb.20204

[18] Florida State University (2011) Chapter 8: Instruction at FSU: A Guide to Teaching \& Learning Practices. 72-102. https://distance.fsu.edu/instructors/instruction-fsu-guide-teaching-learning-practices

[19] POGIL Project Website. https://pogil.org/

[20] Tuan, H.L., Chin, C.C., Tsai, C.C. and Cheng, S.F. (2005) Investigating the Effectiveness of Inquiry Instruction on the Motivation of Different Learning Styles Students. International Journal of Science and Mathematics Education, 3, 541-566. http://dx.doi.org/10.1007/s10763-004-6827-8

[21] Minderhout, V. and Loertscher, J. (2007) Lecture-Free Biochemistry: A Process Oriented Guided Inquiry Approach. Biochemistry and Molecular Biology Education, 35, 172-180. http://dx.doi.org/10.1002/bmb.39

[22] Tessier, J.T. and Penniman, C.A. (2006) An Inquiry-Based Laboratory Design for Microbial Ecology. Bioscene, 32, 6-11.

[23] Gabelica, C. and Fiore, S.M. (2013) What Can Training Researchers Gain from Examination of Methods for ActiveLearning (PBL, TBL, AND SBL). Proceedings of the Human Factors and Ergonomics Society Annual Meeting, 57, 462-466. http://dx.doi.org/10.1177/1541931213571100

[24] Tien, L.T., Roth, V. and Kampmeier, J.A. (2004) A Course to Prepare Peer Leaders to Implement a Student-Assisted Learning Method. Journal of Chemical Education, 81, 1313-1321. http://dx.doi.org/10.1021/ed081p1313

[25] Lewis, S.E. (2011) Retention and Reform: An Evaluation of Peer-Led Team Learning. Journal of Chemical Education, 88, 703-707. http://dx.doi.org/10.1021/ed100689m

[26] Micari, M., Streitwieser, B. and Light, G. (2005) Undergraduates Leading Undergraduates: Peer Facilitation in a Science Workshop Program. Higher Education, 30, 269-288. http://dx.doi.org/10.1007/s10755-005-8348-y

[27] Bridges, E.M. and Hallinger, P. (2007) A Problem-Based Approach for Management Education. Springer, Dordrecht.

[28] Yew, E.H.J. and Schmidt, H.G. (2011) What Students Learn in Problem-Based Learning: A Process Analysis. Instructional Science, 40, 371-395. http://dx.doi.org/10.1007/s11251-011-9181-6

[29] Cook, D.A. and Dupras, D.M. (2004) A Practical Guide to Developing Effective Web-Based Learning. Journal of General Internal Medicine, 19, 698-707. http://dx.doi.org/10.1111/j.1525-1497.2004.30029.x 
[30] Sinav, A. and Ambron, R. (2004) Interactive Web-Based Programs to Teach Functional Anatomy: The Pterygopalatine Fossa. The Anatomical Record, 279B, 4-8. http://dx.doi.org/10.1002/ar.b.20021

[31] Cook, D.A., Garside, S., Levinson, A.J., Dupras, D.M. and Montori, V.M. (2010) What Do We Mean by Web-Based Learning? A Systematic Review of the Variability of Interventions. Medical Education, 44, 765-774. http://dx.doi.org/10.1111/j.1365-2923.2010.03723.x

[32] Minasian-Batmanian, L.C. (2002) Guidelines for Developing an Online Learning Strategy for Your Subject. Medical Teacher, 24, 645-647. http://dx.doi.org/10.1080/0142159021000063998

[33] Tess, P.A. (2013) The Role of Social Media in Higher Education Classes (Real and Virtual)—A Literature Review. Computers in Human Behavior, 29, A60-A68. http://dx.doi.org/10.1016/j.chb.2012.12.032

[34] Prensky, M. (2012) Aprendizagem baseada em jogos. Brazilian Edition: Editora Senac, São Paulo.

[35] Werbach, K. (2013) Gamification Lecture. Pensilvania University. https://class.coursera.org/gamification-002/lecture

[36] Freitas, S. (2006) Learning in Immersive Worlds: A Review of Game-Based Learning. Prepared for the JISC e-Learning Programme. 